\title{
Effect of cycloheximide on the ovine corpus luteum: the role of granules in the secretion of progesterone
}

\author{
R. T. Gemmell* and B. D. Stacy \\ Division of Animal Production, C.S.I.R.O., The Ian Clunies Ross Animal Research Laboratory, \\ Prospect, New South Wales 2148, Australia
}

\begin{abstract}
Summary. Cycloheximide $(3 \mathrm{mg} / \mathrm{h})$ was infused into the corpus luteum of the sheep via a side branch of the ovarian artery. The concentration of progesterone in the peripheral plasma and the luteal tissue decreased after the infusion. Ultrastructural studies showed that cycloheximide caused inhibition of the formation and secretion of densely stained granules in the luteal cells. The results provide further evidence that progesterone bound to protein is secreted by the luteal cell in the form of granules.
\end{abstract}

\section{Introduction}

There is evidence that progesterone is secreted in granule form by the luteal cell of the sheep during the oestrous cycle (Gemmell, Stacy \& Thorburn, 1974). Subsequent work has supported this view since it has been shown that colchicine disrupts the formation and secretion of granules in the luteal cell and at the same time brings about a decrease in the secretion of progesterone (Gemmell \& Stacy, 1977). A recent biochemical, morphological and cytochemical study supports the hypothesis that some of the progesterone in the bovine corpus luteum is sequestered within electron-dense granules (Quirk, Willcox, Parry \& Thorburn, 1979).

The densely staining nature of the luteal secretory granules is thought to be due to protein(s) with special affinity to bind progesterone (Gemmell et al., 1974) and recent autoradiographic and cellular fractionation studies suggest that the granulosa cells of the sheep are active in the synthesis and packaging of a protein for export and that its synthesis and release parallels the synthesis and release of progesterone (Sawyer, McClelland, Abel, Chen \& Niswender, 1977; Abel et al., 1977). To test the validity of this hypothesis the present experiments were undertaken with cycloheximide, a known inhibitor of protein synthesis (Ennis \& Lubin, 1964). The drug was administered by ovarian arterial infusion and the effects of the treatment were observed on the morphology of the luteal cells and on the secretion of progesterone.

\section{Materials and Methods}

Ten (10) adult Merino ewes at pasture were used, and 4 were induced to ovulate by injection with 1000 i.u. PMSG. In all experiments oestrus was detected by daily testing with a vasectomized ram. On Day 10 of the cycle the animals were anaesthetized (induced with sodium pentobarbitone and sustained with halothane and oxygen) and the reproductive organs were displayed by ventral mid-line incision. A small side-branch of the ovarian artery was cannulated with a fine-bore catheter and several ligatures were placed around the vessel to hold the catheter in position. A bolus of dye (Evans blue) was injected and the position of the catheter was deemed

* Present address: Department of Anatomy, University of Queensland, St Lucia, Brisbane, Queensland 4067, Australia. 
satisfactory if the dye, after retrograde passage in the small branch, rapidly entered the main ovarian artery and then the ovary and luteal tissue. Cycloheximide $(0.2 \mathrm{mg} / \mathrm{ml}$ saline $(9 \mathrm{~g}$ $\mathrm{NaCl} / \mathrm{l}$ )) was infused, via the catheter, at $0.25 \mathrm{ml} / \mathrm{min}$ for $2-4 \mathrm{~h}$.

In 4 of the studies, the ovaries were fixed by vascular perfusion with glutaraldehyde immediately after the infusion; details of the perfusion technique and the sampling and processing of tissue for electron microscopy have been described previously (Gemmell et al., 1974). In another 4 studies, the corpora lutea were excised $3 \mathrm{~h}$ after administration of the cycloheximide and the content of progesterone in luteal tissue was determined (Gemmell et al., 1974). The sensitivity of the method was $1 \mu \mathrm{g}$ progesterone/g. In the other 2 sheep, saline was infused into the corpora lutea via the side branch of the ovarian artery.

In all experiments, blood samples from the jugular vein were obtained during the infusion of cycloheximide. The concentration of progesterone in the plasma was determined by the method of Thorburn \& Schneider (1972). The sensitivity was $0.5 \mathrm{ng} / \mathrm{ml}$ and the intra-assay coefficient of variation was $7 \cdot 1 \%$.

\section{Results}

The 4 sheep induced to ovulate with PMSG had a higher pre-infusion concentration of peripheral plasma progesterone $(20.2 \pm 2.8$ (s.e.m.) $\mathrm{ng} / \mathrm{ml})$ than the 4 naturally ovulating sheep $(3.3 \pm 1.3 \mathrm{ng} / \mathrm{ml})$. The plasma progesterone concentration calculated as a percentage of the control level declined after the infusion of cycloheximide (Table 1). This decrease in progesterone concentration in peripheral plasma was accompanied by a decrease in the progesterone content of the luteal tissue; after infusion of cycloheximide for $3 \mathrm{~h}$ the luteal tissue progesterone content $(5.0 \pm 2.7 \mu \mathrm{g} / \mathrm{g}, \mathrm{N}=4)$ was apptoximately $25 \%$ of the control value $(20 \mu \mathrm{g} / \mathrm{g}, \mathrm{N}=10$, Gemmell \& Stacy, 1977). The 2 control saline infusions did not cause any decrease in the progesterone concentration in the peripheral plasma. At Day 10 of the cycle, granules in the corpus luteum were readily seen both within the luteal cell and also in the intercellular space (Pl. 1, Fig. 1). These granules appeared to originate in the Golgi region (Pl. 1, Fig. 2). After a 2-h infusion of cycloheximide, granules could still be observed at the periphery of the cell but very few could be seen in the body of the cell (Pl. 2, Fig. 3). No immature or mature granules were observed in the Golgi regions (Pl. 2, Fig. 4). Granules were still present at the periphery of the cells after infusion for $4 \mathrm{~h}$ but, as with the shorter period $(2 \mathrm{~h})$, granules were not seen in the centre of the luteal cell.

Table 1. Percentage change (mean \pm s.e.m.) in peripheral plasma progesterone concentration in ewes after cycloheximide infusion

\begin{tabular}{lccccccc}
\hline & \multicolumn{7}{c}{ Time after treatment (h) } \\
\cline { 2 - 9 } & 0 & 0.5 & 1 & 1.5 & 2 & 3 & 4 \\
\hline $\begin{array}{l}\text { No. of animals } \\
\begin{array}{l}\text { Plasma } \\
\text { progesterone conc. (\%) }\end{array}\end{array}$ & 8 & 3 & 8 & 3 & 8 & 5 & 1 \\
\hline
\end{tabular}

At each sampling time, the percentage reduction in progesterone concentration for each animal was determined, and the mean and s.e.m. was calculated from all samplings for that time.

\section{Discussion}

Infusion of cycloheximide into the ovarian artery of the sheep at the mid-stage of the oestrous cycle causes a decrease in the concentration of progesterone both in peripheral plasma and in luteal tissue. This change in progesterone status was accompanied by a cytostructural change in the luteal cell. The role of the densely staining granules in the secretion of progesterone in the 
PLATE 1
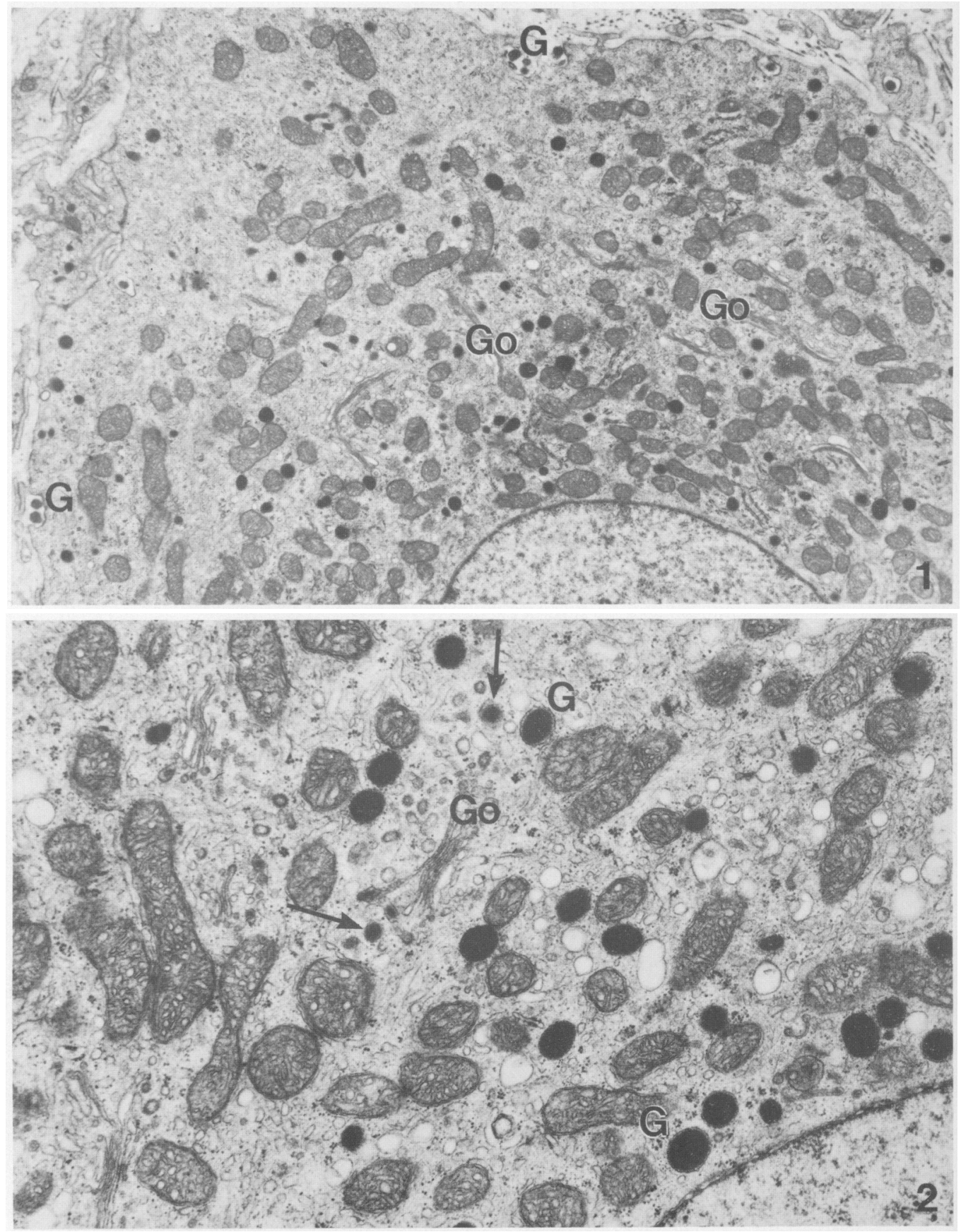

Fig. 1. Part of a luteal cell obtained from a ewe at Day 10 of the oestrous cycle. Granules $(G)$ can be identified within the cell and also in the extracellular space. Golgi regions (Go) are prominent. $\times 7800$.

Fig. 2. A higher magnification of part of a luteal cell from a ewe at Day 10 of the oestrous cycle. Granules $(\mathrm{G}$ and $\rightarrow$ ) can be seen in the Golgi region $(\mathrm{Go}) . \times 22000$.

(Facing p. 88) 
PLATE 2
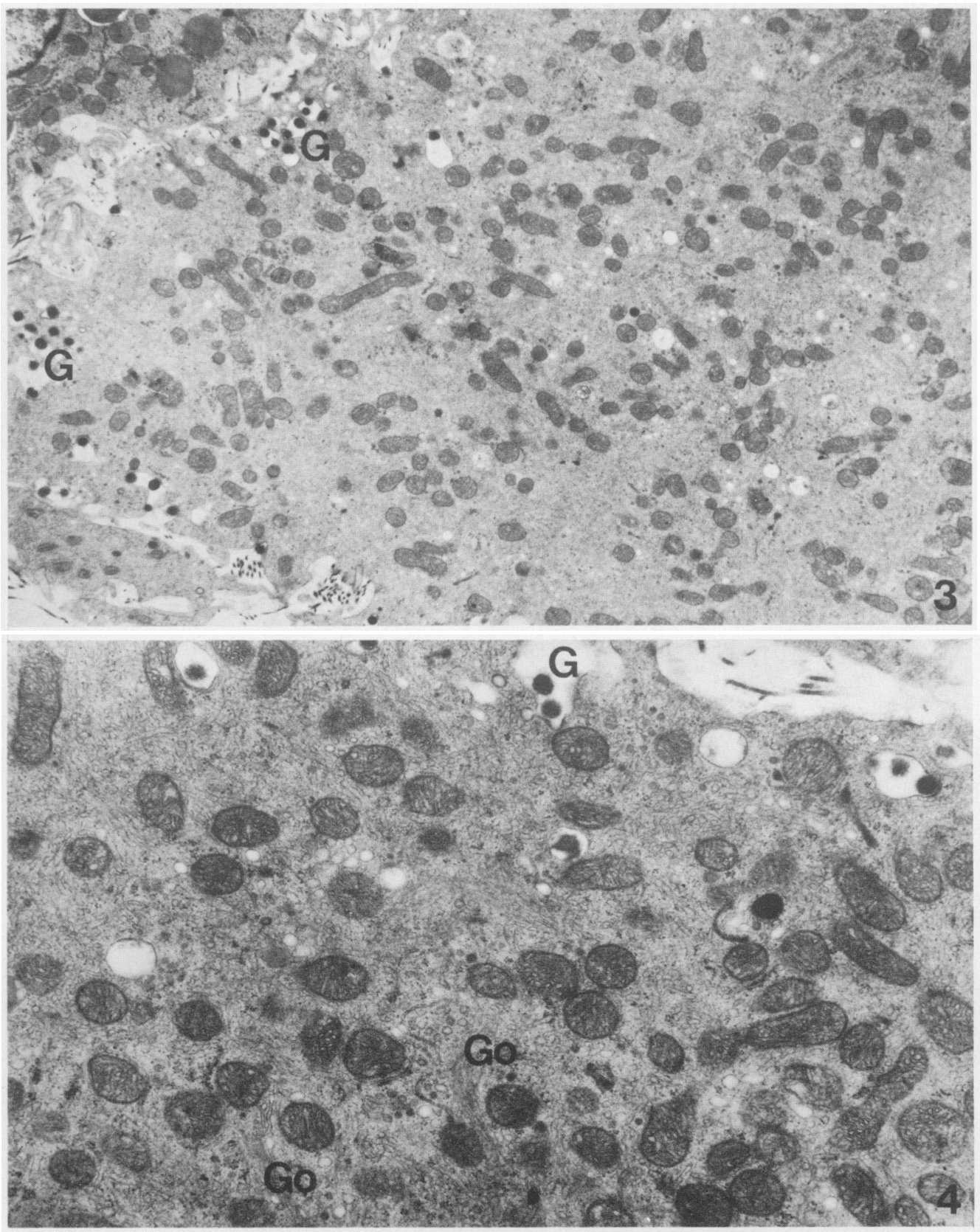

Fig. 3. Part of a luteal cell sampled after infusion of cycloheximide $(3 \mathrm{mg} / \mathrm{h}$, for $2 \mathrm{~h})$ into the ovarian artery. Granules $(\mathrm{G})$ are seen at the periphery of the cell but are scarce within the cell. $\times 5700$.

Fig. 4. Higher magnification of a region of luteal cell after treatment similar to that in Fig. 3 . Very few granules $(\mathrm{G})$ can be observed and the Golgi regions $(\mathrm{Go})$ appear inactive. $\times 18000$. 
cycling ewe has previously been described (Gemmell et al., 1974), and it was noteworthy that cycloheximide interrupted the normal pattern of granule formation and distribution within the cell. At the deeper levels in the cell, granules could no longer be detected. The results indicated that the drug inhibited the synthesis of protein normally packaged into granules for transport to the cell periphery before secretion by exocytosis. Protein and progesterone are presumed to be secreted together (Gemmell et al., 1974; Sawyer et al., 1977; Abel et al., 1977), so the inhibition of granule secretion is a structural feature consistent with the observed suppression of glandular secretory activity.

It is also possible that the granules contain relaxin because there is a positive correlation between the concentration of relaxin in the corpus luteum (Belt, Anderson, Cavazos \& Melampy, 1971) and in the peripheral plasma (Sherwood, Chang, Bevier \& Dziuk, 1975) with the number of granules in the luteal tissue of the pregnant pig. However, the presence of granules does not relate to the concentration of relaxin in the peripheral plasma of the sheep during the oestrous cycle (Chamley, Stelmasiak \& Bryant, 1975). Immunocytochemical studies have suggested that relaxin is present within granules in the corpus luteum of the pregnant pig (Corteel, Lemon \& Dubois, 1977; Kendall, Plopper \& Bryant-Greenwood, 1978), but unfortunately there is no published evidence of relaxin within granules in the luteal cells of any species during the oestrous cycle.

Cycloheximide appeared to influence steroid hormone synthesis as well as secretion since the progesterone content of luteal tissue decreased. The action of this drug therefore was quite different from that of colchicine which has been found to inhibit progesterone secretion only (Gemmell \& Stacy, 1977).

This study provides further evidence that the ovine luteal cell secretes progesterone in the form of granular organelles that originate in the Golgi region.

\section{References}

Abel, J.H., Jr, McClelland, M.C., Sawyer, H.R., Schmitz, M., Niswender, G.D. \& Nau, E. (1977) Synthesis and release of secretory protein from lutein cells. $J$. Cell Biol. 75, 374a.

Belt, W.D., Anderson, L.L., Cavazos, I.F. \& Melampy, R.M. (1971) Cytoplasmic granules and relaxin levels in porcine corpora lutea. Endocrinology 89, 110.

Chamley, W.A., Stelmasiak, T. \& Bryant, G.D. (1975) Plasma relaxin immunoactivity during the oestrous cycle of the ewe. J. Reprod. Fert. 45, 455-461.

Corteel, M., Lemon, M. \& Dubois, M. (1977) Evolution de la reaction immunocytologique du corps jaune de Truie au cours de la gestation. J. Physiol., Paris 73, 63-64A.

Ennis, H.L. \& Lubin, M. (1964) Cycloheximide: aspects of inhibition of protein synthesis in mammalian cells. Science, N.Y. 146, 1474-1476.

Gemmell, R.T. \& Stacy, B.D. (1977) Effects of colchicine on the ovine corpus luteum: role of microtubules in the secretion of progesterone. $J$. Reprod. Fert. 49, 115-117.

Gemmell, R.T., Stacy, B.D. \& Thorburn, G.D. (1974) Ultrastructural study of secretory granules in the corpus luteum of the sheep during the estrous cycle. Biol. Reprod. 11, 447-462.

Kendall, J.Z., Plopper, C.G. \& Bryant-Greenwood, G.D. (1978) Ultrastructural immunoperoxidase demonstration of relaxin in corpora lutea from a pregnant sow. Biol. Reprod. 18, 94-98.

Quirk, S.J., Willcox, D.L., Parry, D.M. \& Thorburn, G.D. (1979) Sub-cellular location of progesterone in the bovine corpus luteum. A biochemical, morphological and cytochemical investigation. Biol. Reprod., in press.

Sawyer, H.R., McClelland, M.C., Abel, J.H., Jr, Chen, T.C. \& Niswender, G.D. (1977) Cellular mechanism involved in the packaging and secretion of a secretory protein from ovarian granulosa lutein cells. Anat. Rec. 187, 706.

Sherwood, O.D., Chang, C.C., Bevier, G.W. \& Dziuk, P.J. (1975) Radioimmunoassay of plasma relaxin levels throughout pregnancy and at parturition in the pig. Endocrinology 97, 834-837.

Thorburn, G.D. \& Schneider, W. (1972) The progesterone concentration in the plasma of the goat during the oestrous cycle and pregnancy. J. Endocr. 52, 23-36. 